\title{
Landslide Dynamics and Determination Critical Condition Using of Resistivity Method in Desa Negeri Lima Ambon
}

\author{
Matheus Souisa $^{1 *}$, Lilik Hendrajaya ${ }^{2}$, Gunawan Handayani ${ }^{3}$ \\ ${ }^{l}$ PhD Student at Earth Physics Section, Department of Physics, Faculty of Mathematics and Natural Science, ITB West Java \\ ${ }^{2,3}$ Senior Lecturer at Earth Physics Section, Department of Physics, Faculty of Mathematics and Natural Science, ITB West Java
}

Received: 8 June 2015, Revised: 23 July 2015, Accepted: 29 July 2015

\begin{abstract}
Ambon Island is a volcanic island arc and included in the territory of the archipelago of small islands are associated with subduction zones that have a high degree of vulnerability to natural disasters, such as erosion and landslides on a particular slope conditions. This study aims to determine the dynamics of avalanches below the surface in the area of the landslide and determine the position of the gelincirnya. The study area in the mountains of Ulak Hatu Negeri Lima Ambon. Research using geoelectric of resistivity with Wenner-Schlumberger configuration. Geoelectric interpretation results correlated with the drill data to obtain landslide field located at a depth of approximately $5 \mathrm{~m}-30 \mathrm{~m}$ and lithology dominated by low resistivity values with the structure of a layer of clay mixed with layers of weathered rock and clay layer with water saturated. Both of these layers contact each other and form the slope of the ground, causing the potential for critical slip thereon and allows the subsequent landslides. Critical location landslide direction of the obliquity of the avalanche that is, toward the cliff and the geometry of the type of debris avalanches of rocks and debris flow. Estimation of landslides occur in addition to the local geological conditions, but strongly influenced by rainfall reached $335.0 \mathrm{~mm}$, earthquakes and coupled with a slope of $119.0 \%$.
\end{abstract}

Keywords: sliding plane, landslides, geoelectric of resistivity

\section{INTRODUCTION}

Ambon Island is part of the Moluccas islands is an islands arc volcanic [1] and included in the territory of the archipelago of small islands associated with subduction zone that has a degree of vulnerability high to natural disasters, such as erosion and landslides on condition of slopes particular.

The results of previous studies, shows Ambon Island region is an area that is prone to landslide hazard to the intensity of catastrophic landslide and floods from year to year are expected to increase more than $60 \%$ [2]. During the years 2011 - 2013, landslides and flooding in the region have resulted in loss of life, destruction of homes, displacement and land use change.

This study focused on the Subdistrict Leihitu of Negeri Lima village, where the date of June 13,

Corresponding author.

E-mail address: txsenwitzne@yahoo.co.id
2012 occurred of debris rock in the mountains Ulak Hatu, causing the formation of natural dams and on July 25, 2013 the dam collapse. After collapse, there are cracks in the side walls of the cliff on the east side of the sea and every occurrence of rain water into the cracks. It is therefore necessary of geoelectric investigation to determine the distribution of the depth of sliding plane to be used as a baseline for consideration of the authorities to help anticipate the possibility of subsequent landslides can form new natural dam and also serve as land-use planning.

\section{THEORY}

Events landslide is the movement of the material forming the slope (3), can be rock original, soil weathering, material pile or a combination of these materials [4] which moves downward and out slopes or falling down a slope [5] as control gravity. Type landslides based of materials that landslide is 
divided into three parts [6], the rocks, debris and soil material. While the main group of ground movement by Hutchinson [7] consists of creep and landslide, which are further divided into sub-groups slides, flow, fall and the slip. According Zaruba and Mencl [8], the cause of landslides is a change in the level of slope, weakening of slope material due to weathering, increased water content, changes in the vegetation of cover the slope and the excess load.

Applications geoelectric resistivity method has been widely used for the survey and exploration of natural resources, such as finding geothermal resources, distribution of hot springs, ground water surveys, the distribution of mineral and land movement or landslides [9]. Geoelectric resistivity method has several configurations namely Schlumberger configuration, Wenner configuration, configuration Square, the configuration of dipoledipole and pole-dipole electrode configuration. This research used the method of geoelectric resistivity with Wenner-Schlumberger configuration. The distance between the electrode potential of "a", while the current electrode and the electrode potential in inner ( $\mathrm{A}$ and $\mathrm{M}$ or $\mathrm{N}$ and $\mathrm{B}$ ) is na, with $\mathrm{n}$ $=1,2,3,4, \ldots$ (Figure 1). In general, the apparent resistivity values $[10]$ can be written as:

$$
\rho_{a}=K \frac{\Delta V}{I}
$$

with $\rho_{\mathrm{a}}$ : apparent resistivity $(\Omega . \mathrm{m}), \Delta V$ : potential difference (volts), $I:$ a current (A), $K=\pi n(n+1) a$ is a geometry factor $(\mathrm{m})$ for the WennerSchlumberger configuration.

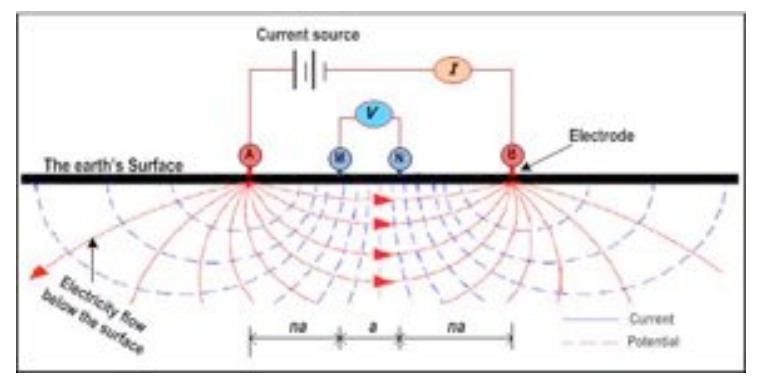

Figure 1. Setting the position of the electrode configuration of WS (adopted from NGA in [11])

\section{RESERACH METHODS}

Surveys track of conducted in the hills Ulak Hatu Desa Negeri Lima Subdistrict Leihitu of Ambon (Figure 2), which is geographically located at coordinates: $03^{\circ} 42^{\prime} 24.2^{\prime \prime}$ until $03^{\circ} 42^{\prime} 22.9^{\prime \prime} \mathrm{SL}$ and $128^{0} 11^{\prime} 11.0^{\prime \prime}$ until $128^{0} 11^{\prime} 12.8^{\prime \prime} \mathrm{EL}$, and $03^{\circ} 45^{\prime} 15.5^{\prime \prime}$ until $03^{\circ} 45^{\prime} 16.3^{\prime \prime}$ SL and $128^{\circ} 07^{\prime} 58.2^{\prime \prime}$ until $128^{0} 07^{\prime} 57.9^{\prime \prime}$ EL. Field resistivity data acquisition performed on six tracks with a space and a different path length (Figure 3).

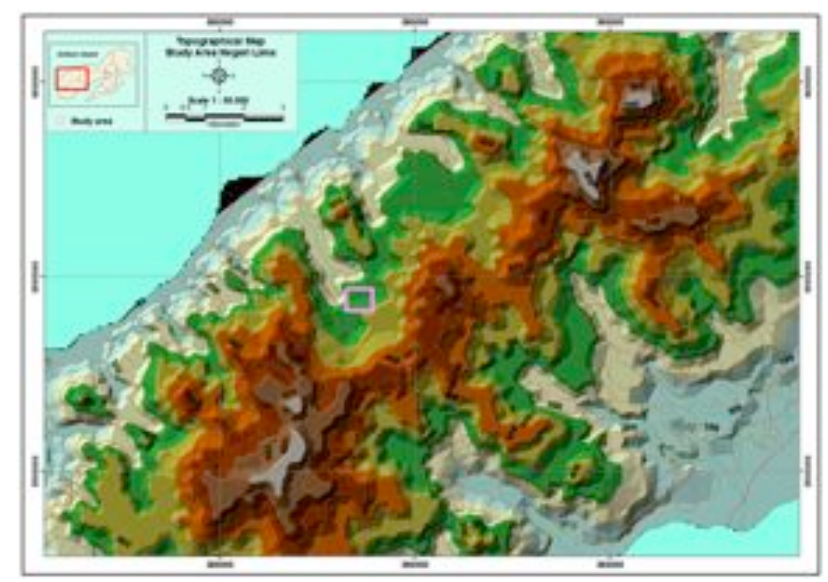

Figure 2. Study area in Desa Negeri Lima Ambon

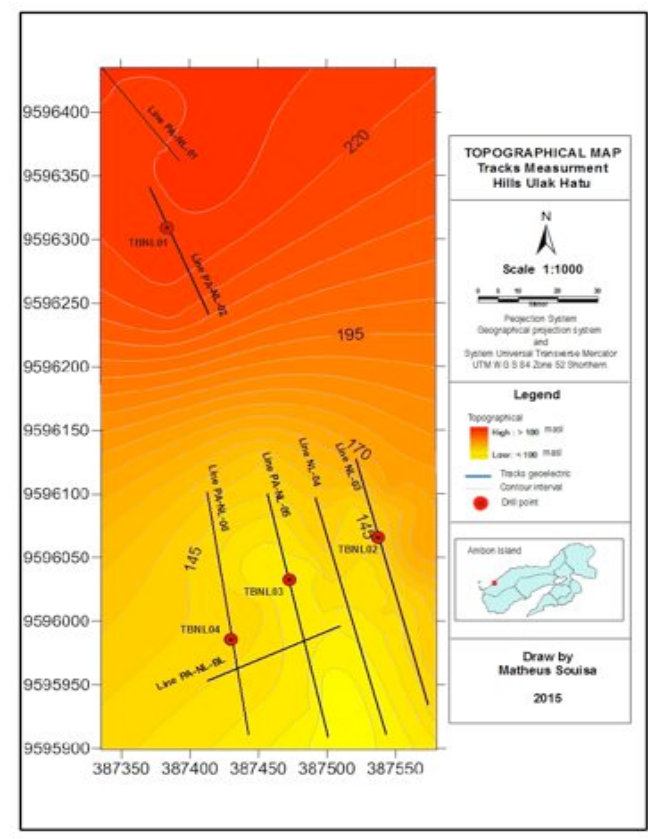

Figure 3. Tracks measurements in the study area

\section{RESULTS AND DISCUSSION}

Based on the results of research in the hills of Ulak Hatu Desa Negeri Lima Ambon, found rock debris landslide type and debris flow. This landslide triggered by high rainfall reached $335.0 \mathrm{~mm}$ [12] occurred at high slope with steep slopes (119.0\%), and occurs in the use of forest land. Alteration of landslide speed that high is highly dependent on the slope height and position of deposition the landslide material.

Image modeling cross-section of resistivity is done by measuring the resistivity point on each tracks. Parameters obtained in the form of apparent resistivity values. This value is correlated to obtain a picture of the physical condition of rock below the 
surface through the interpretation of the results the inversion by using the anomaly map of cross-section in the form of stacked section true resistivity.

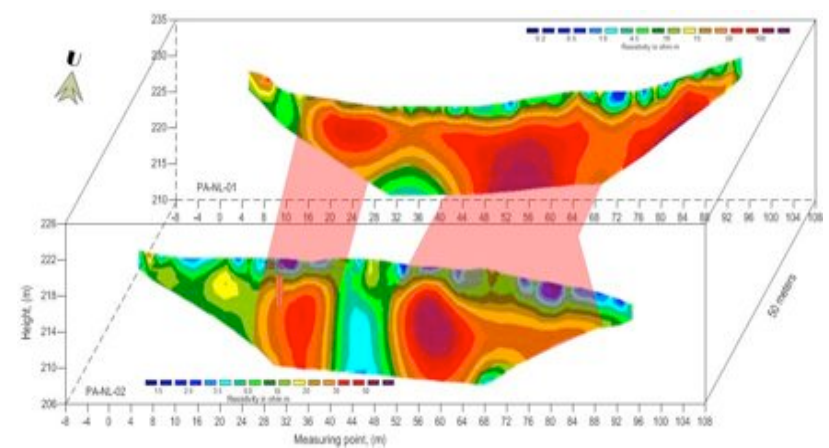

Figure 4. Stacked section true resistivity of tracks NL-01 and NL-02

Stacked section true resistivity (figure 4), dominated by the value of resistivity low to moderate with the appearance of the resistivity distribution NL-01 different from tracks the NL-02 possible occurs at a depth of $2-5 \mathrm{~m}$. Whereas, at a depth of more than $5 \mathrm{~m}$, the appearance of the resistivity distribution NL-01 is also different with NL-02. On the tracks NL-01 there is the possibility of the spread of crack zone / sliding around of points 12-36 and track NL-02 chance of spreading zone of crack / sliding around of points 24-40 and 50-92. Zone crack / slip is a potential landslide aftershocks.

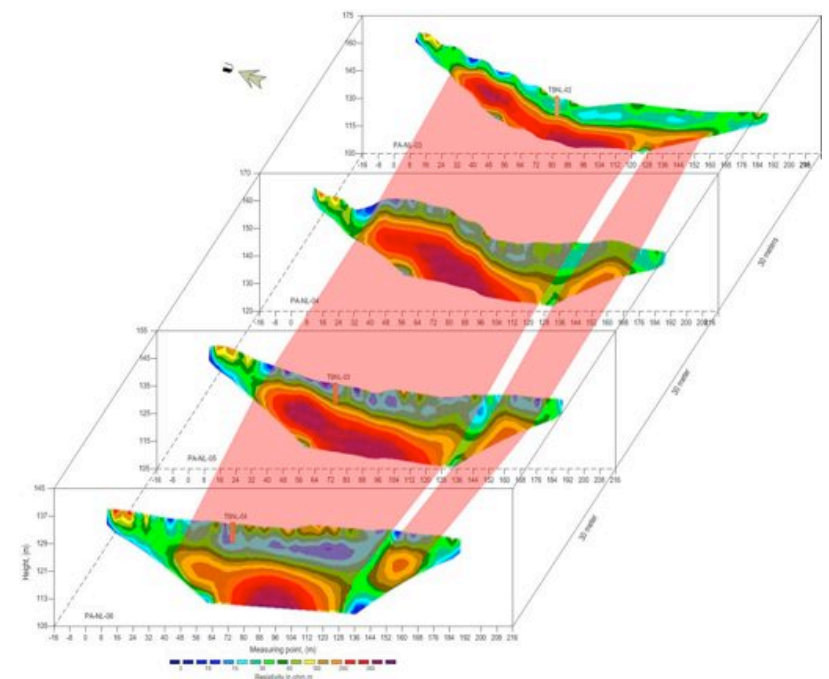

Figure 5. Profile distribution zone impermeable clay on tracks NL-03 to NL-06

Stacked section true resistivity (Figure 5) is dominated by resistivity values are low to moderate with the appearance of the resistivity distribution NL-03 different with the tracks NL-04, NL-05 and NL-06 might happen at a depth of 2-5 m. Meanwhile, at a depth of more than $5 \mathrm{~m}$, appearance of the resistivity distribution NL-03 resembles the NL-04, NL-05 and NL-06. It is possible distribution the zone of sliding around points 8-58 and 136-160 on the track continuously until the NL-03 NL-06 path.

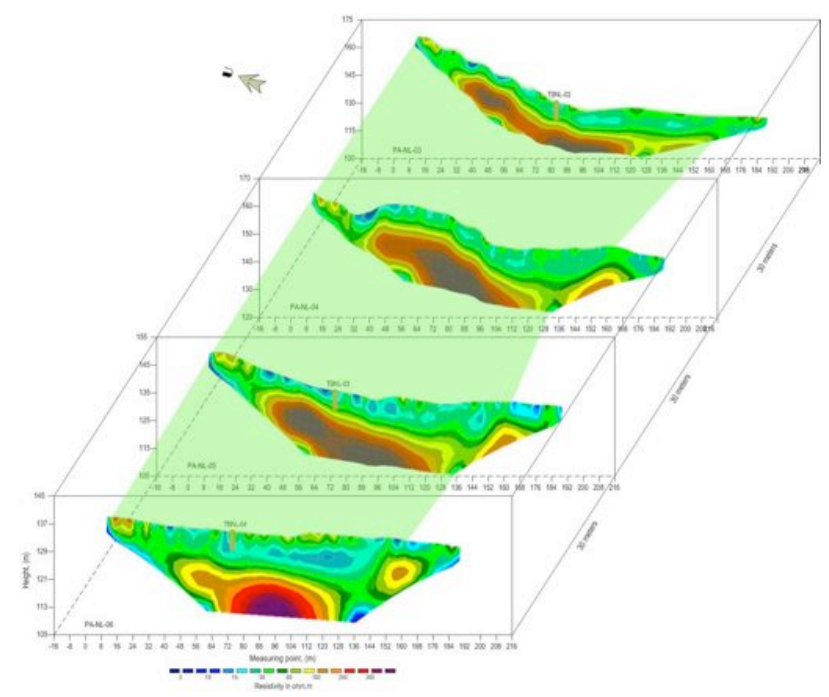

Figure 6. Profile distribution zone permeable clay on tracks NL-03 to NL-06

Anomaly resistivity of landslide distribution on the vertical direction reaches a depth of $15 \mathrm{~m}$ (Figure 4) and $30 \mathrm{~m}$ (Figure 5). This anomalous alteration allows the potential distribution of avalanches remains at its original location in case of disturbances on the slopes and the chance to shift to the northeast with a predicted speed is reduced from the previous landslides. While the direction of the horizontal distribution of landslides in the direction of potential landslide slope direction of the sliding plane which leads to the southwest, it is supported by an increasingly steep topography.

Figure, 5 and 6 , is an indication of zone distribution of clay which shows that the clay zones scattered throughout the study area. Zone of the bottom of the cross-section is composed of chunks or blocks of rock clay (Figure 5) is an impermeable layer and more easily derail massive material thereon. Zone section above the block of clay rocks (Figure 6) is composed of the accumulated layers of clay mixed with weathered rock are permeable in the form of a layer of silt and sandy. Both of these layers contact each other and form the slope of the land surface. This is apparent from the resistivity contrast between two adjacent rocks. When the resistivity of the top layer is much lower than the resistivity of the layer below it is possible avalanches occur. Due to this coating has a heavier load, and the incoming water can not penetrate the layer of clay so that the water will be collected on the surface of the bottom layer that causes cohesion and friction becomes smaller and the layer becomes slippery so easily eroded and flow. As a result give thrust on the slope beyond the retaining force so that the effect on the decrease in shear strength and increased pore pressure, and even supported by fairly steep areas with topography sloping towards 
the river flow and rainfall is very high so the water more easily disappear in this position.

The occurrence of landslides in the study area due to: i) The hills Ulak Hatu entered in the fault lines [13] which may lead to changes in the earth's surface. This fault, including the fault is not active, and can be activated if there is a movement of tectonic plates, resulting in large-scale earthquake and the river channels; ii) alteration of physical properties of rocks through weathering of volcanic rocks Ambon old stuck on the rocks of origin; iii) The soil / rock in a steady incline becomes unstable due to the activity of the people who cleared the land for plantation activities without seeing conditions and topography surrounding area, and iv) Addition of water by high rainfall led to severe soil layer on the slopes are not able to withstand the load contained thereon so that the water seeps into the soil up to a few meters and the saturation number of land mass that is in the lower layer can no longer hold back the masses on top of that layer of soil on the slope becomes critically easily loose and slid at high speed brings considerable energy, The addition of water also causes soil cohesion and friction coefficient decreases from bottom to top.

\section{CONCLUSION}

Landslides in the area of research is a type of debris rock and debris flow, is prediction due to the penetration of rain water with a high slope and steep. Layer that alleged as sliding plane is a layer of volcanic rocks Ambon. Anomaly resistivity of landslides distribution in the vertical direction allegedly obtained the resistivity contrast between two rocks adjacent to each other and cause a potential slip thereon. At the direction of the horizontal of landslide distribution follow the direction of the slope of the critical position with the direction toward a cliff landslide.

Landslide mitigation is necessary to avoid subsequent landslide with land use planning through greening to avoid of areas landslides and carried out activities around the slopes.

\section{ACKNOWLEDGMENT}

The authors are grateful to the Earth Physics Laboratory Faculty of Mathematics and Natural Sciences Unpatti Ambon, the Department ESDM of Province Moluccas, and Ministry of Public Works Central River Region Maluku for their assistance in completing the data retrieval.

\section{REFERENCES}

[1] Anonim (1), "Evaluasi Hasil Pelaksanaan RKPD Tahun Lalu Dan Capaian Kinerja Penyelenggaraan Pemerintahan", Rencana Kerja Pemerintah Kota Ambon Tahun 2014. pp.6-7.

[2] M. Souisa, L. Hendrajaya dan G. Handayani, "Investigasi Awal Mekanisme Tanah Longsor di Pulau Ambon", Provinsi Maluku, Prosiding Seminar Basic Sains VI, FMIPA Ambon, Agustus 2014, pp.23-32.

[3] D.J, Varnes, "Slope Movement and Type and Processes, Landslide Analysis and control", Transportation Research Board, special Report 176, Washington D.C. : National Research Council, 1978.

[4] D.M. Cruden, "A Simple Definition of Landslide", Bulletin of The International Association of Engineering Geology 1991, p.43.

[5] J. Cepeda, H. Smebye, B. Vangelsten, F.Nadim, and D.Muslim, "Landslide Risk In Indonesia", Global Assessment Report, 2011, p.2.

[6] M.A.Sroor, "Geology and Geophysics in Oil Exploration, 2010, pp.134-135.

[7] J.N. Hutchinson, "Morphological And Geotechnical Parameters of Landslides: in Realtion to Geology and Hydrogeology",. Symposium Landslide, 1988, vol.1: 3 - 15.

[8] Q. Zaruba and V. Mencl, "Landslides and Their Control", Second completely revised edition, Elsevier Scientific Publishing Company, Amsterdam, 1982, p.13.

[9] D.H. Griffiths, and R.D. Barker, "Two Dimensional Resistivity Imaging and Modelling in Areas of Complex Geology", Journal of Applied Geophysics, 1993, V.29. pp.211-226.

[10] R. Kirsch, "Groundwater Geophysics: A tool for hydrogeology", Springer Berlin Heidelberg, New York, 2006, pp.85-88.

[11] M.Souisa, L. Hendrajaya, and G. Handayani, "Determination of Landslide Slip Surface Using Geoelectrical Resistivity Method at Ambon City Moluccas-Indonesia", IJTAE, Volume 5, Issue 5, July 2015, pp.42-47.

[12] Anonim (2), Data Curah Hujan Manual Wai Ela Tahun 2013, Kementerian Pekerjaan Umum, Balai Wilayah Sungai Maluku.

[13] Tjokrosapoetro S., Rusmana E., dan A.Achdan, "Peta Geologi Lembar Ambon, (Geological Map of the Ambon Sheet, Maluku)". Direktorat Jenderal Geologi dan Sumberdaya Mineral, Pusat Penelitian dan Pengembangan Geologi, Bandung, 1994 